\title{
Patterns of vegetation composition across levels of canopy disturbance in temperate forests of west Himalaya, India
}

\author{
Subodh Airi* \& Ranbeer S. Rawal
}

Biodiversity Conservation and Management Theme, G. B. Pant National Institute of Himalayan Environment and Sustainable Development, Kosi-Katarmal, Almora 263 643, Uttarakhand, India

* corresponding author (e-mail: airisubodh@gmail.com)

\begin{abstract}
This study analyses the impacts of canopy disturbance on vegetation compositional attributes of two characteristic temperate forests (i.e., mixed broad-leaf and banj-oak forests) in west Himalayan part of India. Following the standard approaches, quantitative information on compositional attributes of forest vegetation was generated and analyzed. Considerable changes in these attributes were revealed across different levels of canopy disturbance in both forests. In particular, tree density and total basal area (TBA) exhibited significant decline from undegraded to degraded stands. Among others, seedling and sapling density of mixed broad-leaf forest was affected adversely by increased level of canopy disturbance. However, herb density in this forest increased significantly with increasing levels of disturbance; the same was not true for banj-oak forest. A significant decline in relative frequency and density of native herbaceous species was apparent towards degraded stands, implying that the disturbed sites in both forests created an opportunity for the establishment and proliferation of non-natives. However, with significant increase in relative density of non-native herbs, the degraded stands of banj-oak forest emerged as critically vulnerable to non-native proliferation. The patterns of tree size class distribution in both forests also exhibited certain trends across canopy disturbance, which suggested possible future changes in composition. In particular, the patterns of common tree associates (i.e., Myrica esculenta and Rhododendron arboreum) in banj-oak forest and Pinus roxburghii in mixed broad-leaf forest were indicative of likely compositional changes in near future. The study concludes that: (i) compositional attributes of both mixed broad-leaf and banj-oak forests were sensitive to increasing levels of canopy disturbance, (ii) mixed broad-leaf forest exhibited greater sensitivity to canopy disturbance at recruitment levels, (iii) increased canopy disturbance led to establishment and proliferation of non-native species in the herbaceous layer of both forests, and (iv) banj-oak forest exhibited high vulnerability to non-native proliferation at degraded stage.
\end{abstract}

Key words: temperate forests, plant diversity, mixed broad-leaf, banj-oak, non-native proliferation, compositional change

\section{Introduction}

Structural and functional aspects of diverse forest communities in the Indian Himalayan Region have been elaborately described (Singh \& Singh 1987, 1992; Rawal 1991; Singh et al. 1994; Adhikari et al. 1995; Dhar et al. 1997; Gairola et al. 2008; Kharkwal \& Rawat 2010). Also, it is well recognized that the forests of the region have been subject to pressures for centuries due to subsistence use of forest resources by inhabitants (Singh \& Singh 1992). Evidence generated over the years suggest increased exploitation pressure on these forests (Pandey \& Singh 1984; Ram et al. 2004) that led to canopy distur- bances and caused changes in structural and functional attributes of these forests (Ram et al. 2004; Kumar \& Ram 2005; Gairola et al. 2009, Gairola et al. 2015). However, this fact remained grossly unattended while defining forest management plans for the region. This can partially be explained on account of inadequate evidence, which could help in describing the response patterns of forest species and/or communities across intensities and types of disturbances. Very few attempts have been made on Himalayan forests to compare the forest responses (species and/or communities) to various levels and types of disturbance (Ram et al. 2004; Gairola et al. 2009; Uniyal et al. 2010; Rawal et al. 2012). 
While defining various types of forest disturbances and the associated impacts, Singh (1998) discussed two types of disturbances: $(i)$ acute disturbance that involved logging selectively or clear cutting, which allowed forests to regenerate by natural means, and (ii) chronic disturbance, which was subtle and slowly creeping and often did not allow forests to regenerate. The west Himalayan forests mostly suffer from the chronic form of disturbance. This form of forest disturbances, on account of never ending human onslaught, are not only associated with habitat alterations by way of increasing soil compaction and consequent increase in runoff water, but also cause loss of litter and nutrients and, thereby, changes in herb species composition, etc. However, study-based evidence is not available to clearly indicate intensity and directions of changes in forest vegetation due to prevailing chronic disturbances on Himalayan forests.

Motivated by the above facts, we conducted a systematic study on representative temperate forests of west Himalaya keeping the following two broad hypotheses in mind: $(i)$ the increasing level of canopy degradation significantly impacts compositional attributes of forest vegetation; and (ii) the sensitivity of forest composition towards canopy degradation would vary across forest types.

\section{Material and methods}

\subsection{Subject of the study}

Two representative temperate forests (i.e., banj-oak Quercus leucotrichophora) and mixed broad-leaf forest)], which are characteristic of mid-altitude zone (1200-2500 m asl) in west Himalaya, were selected for this study. Both forests fall under broad-leaf category. Q. leucotrichophora forest is described as a hemisclearophyllous broad-leaf forest with concentrated summer leaf drop; it often remains closed canopied and forms extensive forests between 1200-2200 m a.s.1. on mesic to sub-mesic sites. This forest exhibits a clearly discernible dominance of $Q$. leucotrichophora (Singh \& Singh 1987), whereas the mixed broad-leaf forests occupy altitude range similar to banj-oak forests and the associated species, by and large, remain similar. However, in this type of forest, none of the tree species, including banj-oak, exhibit clearly discernible dominance. Both forests, being located in a heavily humaninhabited zone of the region and having useful species for fulfilling subsistence needs (e.g., fodder and fuel) of local inhabitants, face continuous and similar type of pressure from biomass harvesting by rural populace.

Three representative sites namely Syaidevi $\left(29^{\circ} 35^{\prime} \mathrm{N}\right.$ Lat, 79 35'E Long); Kukucheena ( $30^{\circ} 31^{\prime}$ N Lat, 79 $52^{\circ}$ E Long) and Jalna (29 $32^{\prime} \mathrm{N}$ Lat, $79^{\circ} 44^{\prime}$ E Long) were selected between 1200-2400 m altitude a.s.l. In each site, both types of forests were targeted. Considering the canopy disturbance, each forest type was classified into three levels of degradations: (i) undegraded: $>70 \%$ tree individuals with intact canopy; (ii) semi degraded: 40$70 \%$ tree individuals with intact canopy; (iii) degraded: $<40 \%$ tree individuals with intact canopy.

\subsection{Vegetation analysis}

In each study site, vegetation sampling was conducted along a representative vertical belt transect (approximately $400 \mathrm{~m}$ long and $50 \mathrm{~m}$ wide) in every disturbance condition. Sample stands $(100 \times 30 \mathrm{~m})$ were marked, one each at three positions (viz. base, middle and top) of the transect. In each position, ten quadrats $(10 \times 10 \mathrm{~m})$ for trees and ten sub quadrats $(5 \times 5 \mathrm{~m})$ for shrubs, seedling and sapling were laid randomly. For herbaceous species, two $(1 \times 1 \mathrm{~m})$ sub quadrats were laid within each $5 \times 5 \mathrm{~m}$ sub-quadrat. Quadrat data were pooled for stands to compute density, frequency, total basal area (TBA), and Important Value Index (IVI) following Misra (1968) and Mueller-Dombois and Ellenberg (1974). Using density data, the diversity index $\left(H^{\prime}\right)$ was calculated following Shannon-Wiener diversity index (Shannon \& Wiener 1963).

The tree population structures were developed following density distribution in different size classes. Tree species individuals were grouped under six arbitrary CBH (Circumference at Breast Height) classes: $\mathrm{A}-<11$ (seedling); $\mathrm{B}-11-30$ (sapling); tree classes as $\mathrm{C}-31$ 60; D - 61-90; E-91-120; F->121 cm CBH.

\subsection{Statistical analysis}

Parametric statistical analyses (Correlation and ANOVA) were conducted using the SYSTAT Computation package (Wilkinson 1986). Relationships were developed using pooled plot data. Significance differences among means were separated by using Fitsher's least significant difference (LSD) representativeness of herbaceous species across disturbance levels was analysed using Chi-Square $\left(\chi^{2}\right)$ test (Snedecor \& Cochran 1969).

\section{Results}

\subsection{Vegetation structure of mixed broad-leaf forest}

While considering the level of canopy disturbance, this forest showed a characteristic decline in tree species richness from undegraded (16 spp) to degraded stands (8 spp). As such, none of the tree species could exhibit clear dominance; however, banj-oak (Q. leucotrichophora) emerged as the most important species of undegraded (IVI - 91) and degraded stands (IVI - 75), whereas chir-pine (P. roxburghii) exhibited the highest IVI (5) in semi degraded stands. The co-dominant species varied from Rhododendron arboreum (IVI - 58) in 
Table 1. Compositional features of target forests under different disturbance levels in west Himalaya

\begin{tabular}{|c|c|c|c|c|c|c|c|c|c|}
\hline \multirow[b]{2}{*}{$\begin{array}{l}\text { Disturbance } \\
\text { level }\end{array}$} & \multicolumn{5}{|c|}{ Tree } & \multicolumn{2}{|c|}{ Shrub } & \multicolumn{2}{|c|}{ Herb } \\
\hline & $\begin{array}{c}\text { Density } \\
\text { (indi } \\
\text { ha }^{-1} \text { ) }\end{array}$ & $\begin{array}{c}\text { TBA } \\
\left(\mathrm{m}^{2} \mathrm{ha}^{-1}\right)\end{array}$ & $\begin{array}{c}\text { Species } \\
\text { richness \& } \\
\text { Diversity } \\
\left(\mathrm{H}^{-}\right)\end{array}$ & $\begin{array}{l}\text { Seedling } \\
\text { Density } \\
\left(\text { indi ha-1) }^{-1}\right.\end{array}$ & $\begin{array}{l}\text { Sapling } \\
\text { Density } \\
\text { (indi ha-1) }\end{array}$ & $\begin{array}{l}\text { Density } \\
\text { (indi ha-1) }\end{array}$ & $\begin{array}{c}\text { Species } \\
\text { richness \& } \\
\text { Diversity } \\
\left(\mathrm{H}^{-}\right)\end{array}$ & $\begin{array}{l}\text { Density } \\
(\text { indi ha-1) }\end{array}$ & $\begin{array}{c}\text { Species } \\
\text { richness \& } \\
\text { Diversity } \\
\left(\mathrm{H}^{-}\right)\end{array}$ \\
\hline \multicolumn{10}{|c|}{ Banj-oak forest } \\
\hline $\mathrm{U}$ & 789 & 26.88 & $9(-0.59)$ & 4,227 & 2,026 & 1,488 & $11(-2.16)$ & $24,31,300$ & $63(-3.08)$ \\
\hline S & 582 & 17.02 & $10(-0.68)$ & 4,404 & 1,520 & 5,024 & $13(-1.85)$ & $32,45,000$ & $68(-2.97)$ \\
\hline $\mathrm{D}$ & 393 & 11.32 & $10(-0.65)$ & 4,516 & 1,168 & 7,124 & $21(-2.43)$ & $45,68,800$ & $65(-2.68)$ \\
\hline LSD & 133.78 & 11.53 & & $1,455.92$ & $1,210.33$ & $5,006.30$ & & $1,81,225.06$ & \\
\hline $\mathrm{F}$ & $21.77 * * *$ & $9.24 * *$ & & 0.39 & 3.89 & 3.44 & & 4.01 & \\
\hline \multicolumn{10}{|c|}{ Mixed broad leaf forest } \\
\hline $\mathrm{U}$ & 1,155 & 32.09 & $16(-1.74)$ & 7,800 & 5,000 & 6,184 & $10(-1.52)$ & $24,41,300$ & $69(-2.84)$ \\
\hline $\mathrm{Sd}$ & 973 & 23.31 & $16(-0.51)$ & 6,422 & 3,106 & 8,072 & $15(-2.56)$ & $43,11,800$ & $64(-2.93)$ \\
\hline $\mathrm{D}$ & 738 & 16.27 & $8(-1.43)$ & 5,404 & 1,888 & 7,724 & $13(-2.10)$ & $51,52,900$ & $54(-2.55)$ \\
\hline LSD & 135.00 & 2.59 & & $2,015.77$ & 659.50 & $4,516.80$ & & $1,46,909.00$ & \\
\hline $\mathrm{F}$ & $23.84 * * *$ & $92.59^{* * *}$ & & $16.89^{* * *}$ & $56.72^{* * *}$ & 0.10 & & $8.82 * *$ & \\
\hline
\end{tabular}

Explanations: level of significance, $*-p<0.05 ; * *-p<0.01 ; * * * p<0.001 ; \mathrm{U}-$ undegraded; $\mathrm{Sd}-$ semi degraded $\& \mathrm{D}-$ degraded. Values in parenthesis include diversity index $\left(\mathrm{H}^{-}\right)$

undegraded stands, Q. lecucotrichophora (IVI - 69.4) in semi degraded stands to P. roxburghii (IVI - 60) in degraded stands.

The mean forest tree density across levels of canopy disturbance varied from 738 (degraded) to 1,155 indi ha $^{-1}$ (undegraded) and this variation was significant $(\mathrm{F}=23.84, p<0.001)$. A difference ranging between 16.27 (degraded) to $32.09 \mathrm{~m}^{2}$ ha $^{-1}$ (undegraded) was observed for mean TBA (Total Basal Area), which was significant $(\mathrm{F}=92.59, p<0.001)$. Mean tree seedling density declined significantly $(\mathrm{F}=16.89 ; p<0.001)$ from undegraded $\left(7,800\right.$ indi ha $\left.{ }^{-1}\right)$ to degraded $(5,404$ indi $\left.\mathrm{ha}^{-1}\right)$ stands. Likewise, a significant $(\mathrm{F}=56.72 ; p<0.001)$ decrease in sapling density (undegraded $-5,000$; degraded $-1,888$ indi ha $^{-1}$ ) was revealed across gradient of canopy disturbance (Table 1).

The shrub density did not vary significantly across disturbance levels of canopy and semi degraded stands exhibited the highest density $\left(8,072\right.$ indi ha $\left.^{-1}\right)$. On the contrary, across disturbance levels, herb density varied significantly $(\mathrm{F}=8.82, p<0.01)$, which was significantly higher in degraded stands. While considering the species richness, in case of trees and herbs, it varied significantly ( $\mathrm{F}=28.36, p<0.01$ and $\mathrm{F}=24.80, p<0.01$ respectively), whereas the same was not true for shrubs. The diversity index $\left(\mathrm{H}^{\prime}\right)$ was maximum for undegraded stands (1.74) for trees. However, for shrub (2.56) and herb layer (2.93), diversity index remained maximum at semi degraded conditions. Broad patterns of compositional attributes across disturbance levels are depicted (Fig. 1).

\subsection{Vegetation structure of Banj-oak forest}

This forest was less tree species rich (range 9 to 10 spp) and species richness remained unaffected of canopy disturbance. The forest showed a clear dominance of banj-oak ( $Q$. leucotrichophora) with IVI range between 195 (undegraded) to 247 (semi degraded). While Litsea umbrosa remained the co-dominant species at undegraded (IVI - 44) and semi degraded (IVI - 17.8) stands, P. roxburghii (IVI - 26) assumed this position at degraded stands.

The mean forest tree density varied significantly ( $\mathrm{F}=21.77, p<0.001$ ) from 393 (degraded) to 789 indi $\mathrm{ha}^{-1}$ (undegraded). Also, significant variations ( $\mathrm{F}=9.24$, $p<0.01)$ in TBA was apparent $\left[11.32 \mathrm{~m}^{2} \mathrm{ha}^{-1}\right.$ (degraded) to $26.88 \mathrm{~m}^{2} \mathrm{ha}^{-1}$ (undegraded)]. Sapling density exhibited non significant but declining trends $(2,026-1,168$ indi ha ${ }^{-1}$ ) with an increasing level of disturbance. However, seedling density, shrub and herb density showed increasing but non significant trends (Table 1, Fig. 1). The diversity index values remained maximum at undegraded stands for herbs $(\mathrm{H}-3.08)$, at degraded stands for shrubs $(\mathrm{H}-2.34)$, and semi degraded stands for trees $(\mathrm{H}-0.68)$.

\subsection{Patterns of nativity}

While comparing presence of native species on the basis of relative frequency, both banj-oak $\left(\chi^{2}=8.463\right.$, $p<0.05)$ and mixed forest $\left(\chi^{2}=3.725, p<0.05\right)$ showed significant differences in the presence of native, non- 

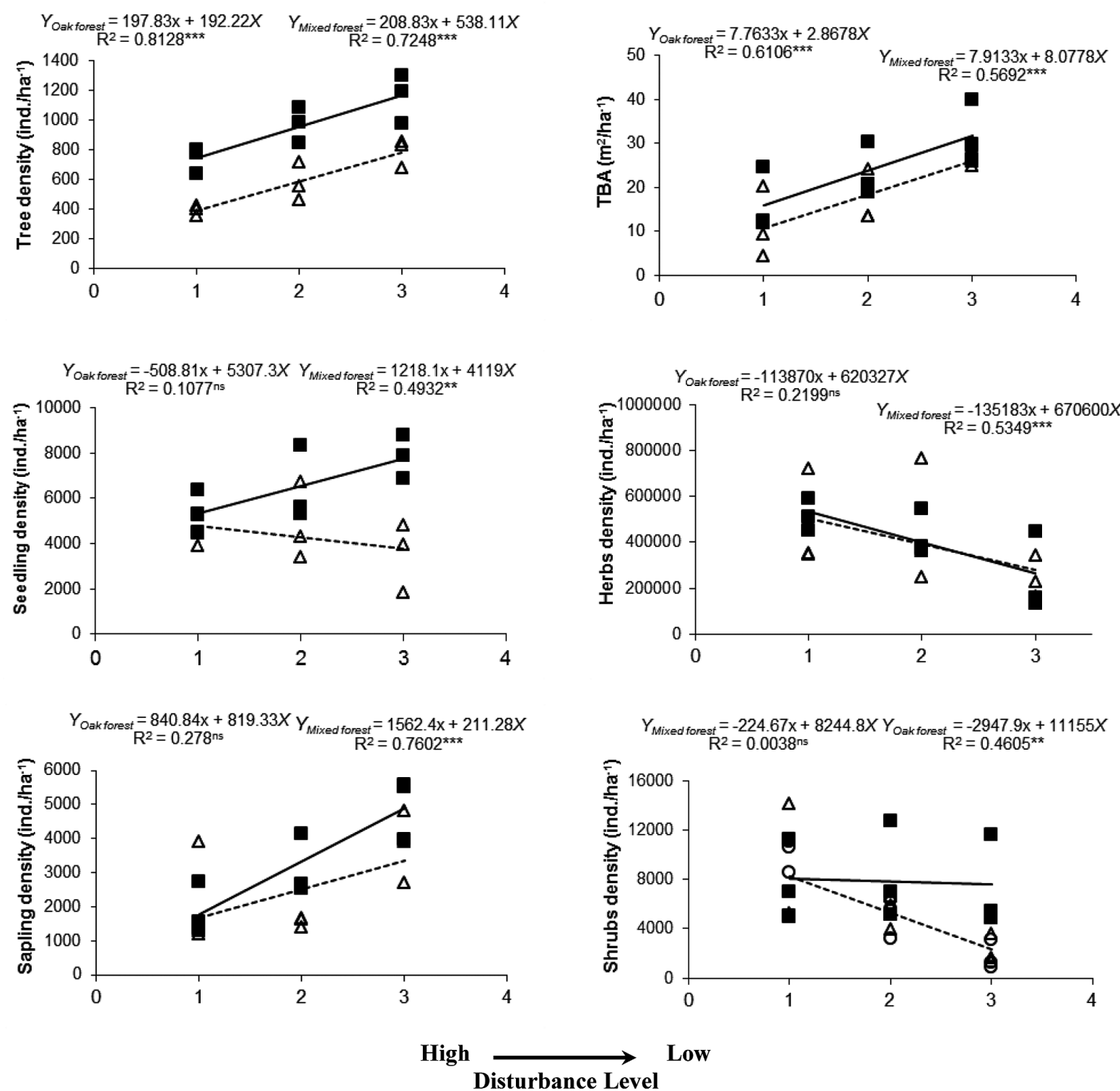

Fig. 1. Relationship between various compositional features of banj-oak and mixed broad-leaf forest along disturbance gradient Explanations: $\mathbf{-}$ - mixed broad leaf forest, $\triangle$ - banj-oak forest; 1 - gegraded, 2 - semi-degraded, 3 - un-degraded, $* * *-p<0.01, * *-p<0.05$, ns - non significance

native species across disturbance levels. However, considering the relative density (as measure of dominance), the differences across disturbance levels were significant in case of banj-oak $\left(\chi^{2}=4.3091, p<0.05\right)$ forest only (Table 2).

\subsection{Forest structure}

The tree size class profiles of target forests, under different disturbance levels, mostly exhibited an overall similarity of structures. Relatively greater seedling density in degraded and semi degraded conditions was characteristic of both forests. In case of banj-oak forest, degraded stands showed a characteristic decline of individuals in small tree stages (Fig. 2), whereas, for mixed broad-leaf forest, the patterns across all disturbance levels remained more or less similar (Fig. 3).
Specific trends of tree size class distribution for target forests were as follows: $(i)$ stands of mixed broad-leaf forest, in general, showed greater density of seedlings and saplings. Q. leucotrichophora showed frequent presence in seedling and sapling stages in all three conditions. However, in degraded and semi degraded stands, greater proportions of individuals in seedling (76.9\%) and sapling (18.00\%) stages were noticed for P. roxburghii. This species did not exhibit frequent presence in undegraded stands. In general, the undegraded stands exhibited greater proportion of saplings and young tree individuals; (ii) In banj-oak forest, size class profiles of dominant species (i.e., Q. leucotrichophora) characteristically showed greater accumulation of individuals in young tree class, and a slight deviation with the population structure for entire forest in degraded 
Table 2. Native and non native herb species performance across disturbance levels in target forests of west Himalaya

\begin{tabular}{|c|c|c|c|c|}
\hline & \multicolumn{2}{|c|}{$\mathrm{RF} \%$} & \multicolumn{2}{|c|}{$\mathrm{RD} \%$} \\
\hline Condition & Native & Non-native & Native & Non-Native \\
\hline \multicolumn{5}{|c|}{ Banj-oak forest } \\
\hline Degraded & 12.54 & 87.46 & 1.64 & 98.36 \\
\hline Semi degraded & 19.77 & 80.23 & 4.88 & 95.12 \\
\hline Undegraded & 28.93 & 71.07 & 8.04 & 91.96 \\
\hline & \multicolumn{2}{|c|}{$\chi^{2}=8.4626$} & \multicolumn{2}{|c|}{$\chi^{2}=4.3091$} \\
\hline & \multicolumn{2}{|c|}{$d f-1, p<0.05$} & \multicolumn{2}{|c|}{$d f-1, p<0.05$} \\
\hline Degraded & 13.71 & 86.29 & 2.02 & 97.98 \\
\hline Semi degraded & 28.34 & 71.66 & 2.15 & 97.85 \\
\hline \multirow[t]{3}{*}{ Undegraded } & 37.43 & 62.57 & 4.95 & 95.05 \\
\hline & \multicolumn{2}{|c|}{$\chi^{2}=3.725$} & \multicolumn{2}{|c|}{$\chi^{2}=1.882$} \\
\hline & \multicolumn{2}{|c|}{$d f-1, p<0.05$} & \multicolumn{2}{|c|}{$d f-1, \mathrm{~ns}$} \\
\hline
\end{tabular}

Explanations: RF - Relative Frequency, RD - Relative Dominance, df - degree of freedom
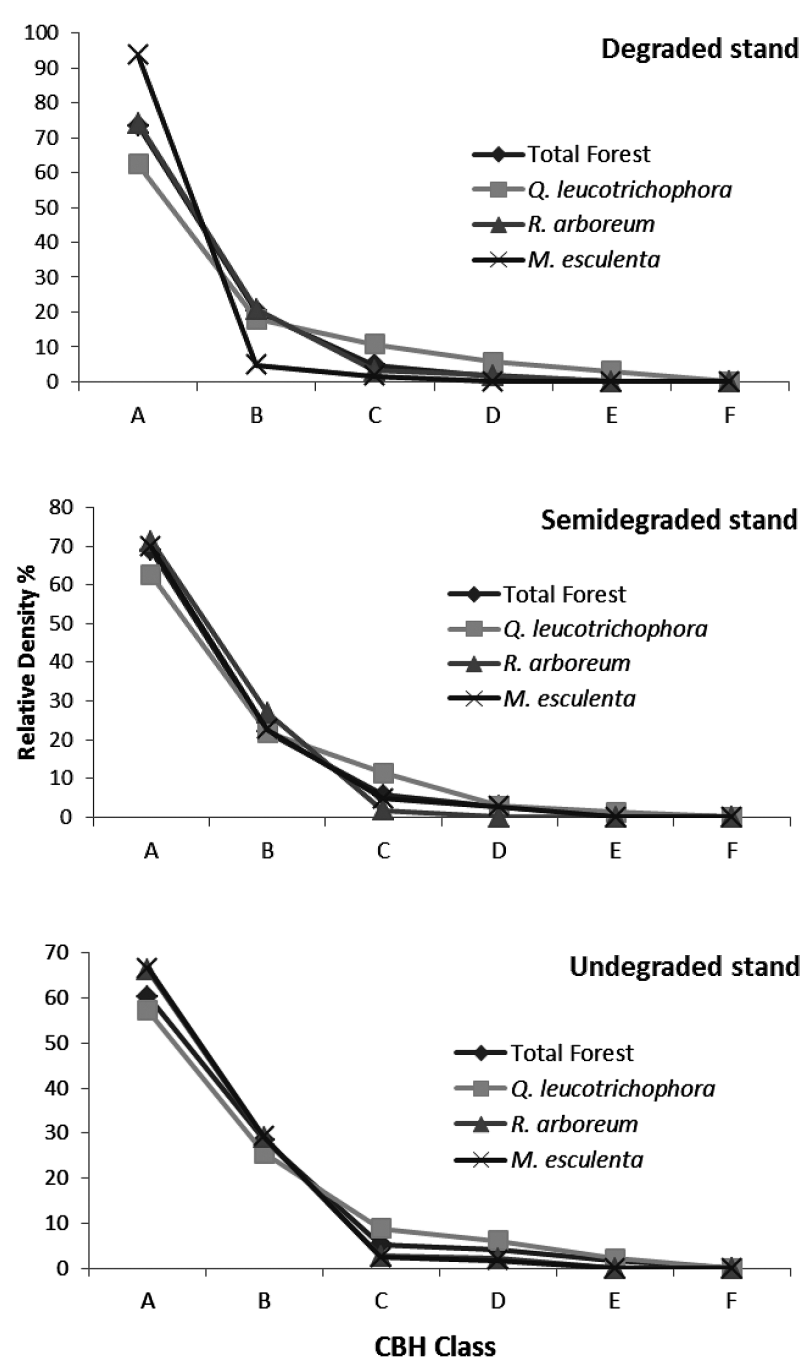

Fig. 2. Patterns of tree size class distribution across disturbance level in Banj-oak forest

Explanations: A - Seedling, B - Sapling, C - 31-60, D - 61-90, E - 91-120, $\mathrm{F}->121 \mathrm{~cm}$ at $\mathrm{CBH}$
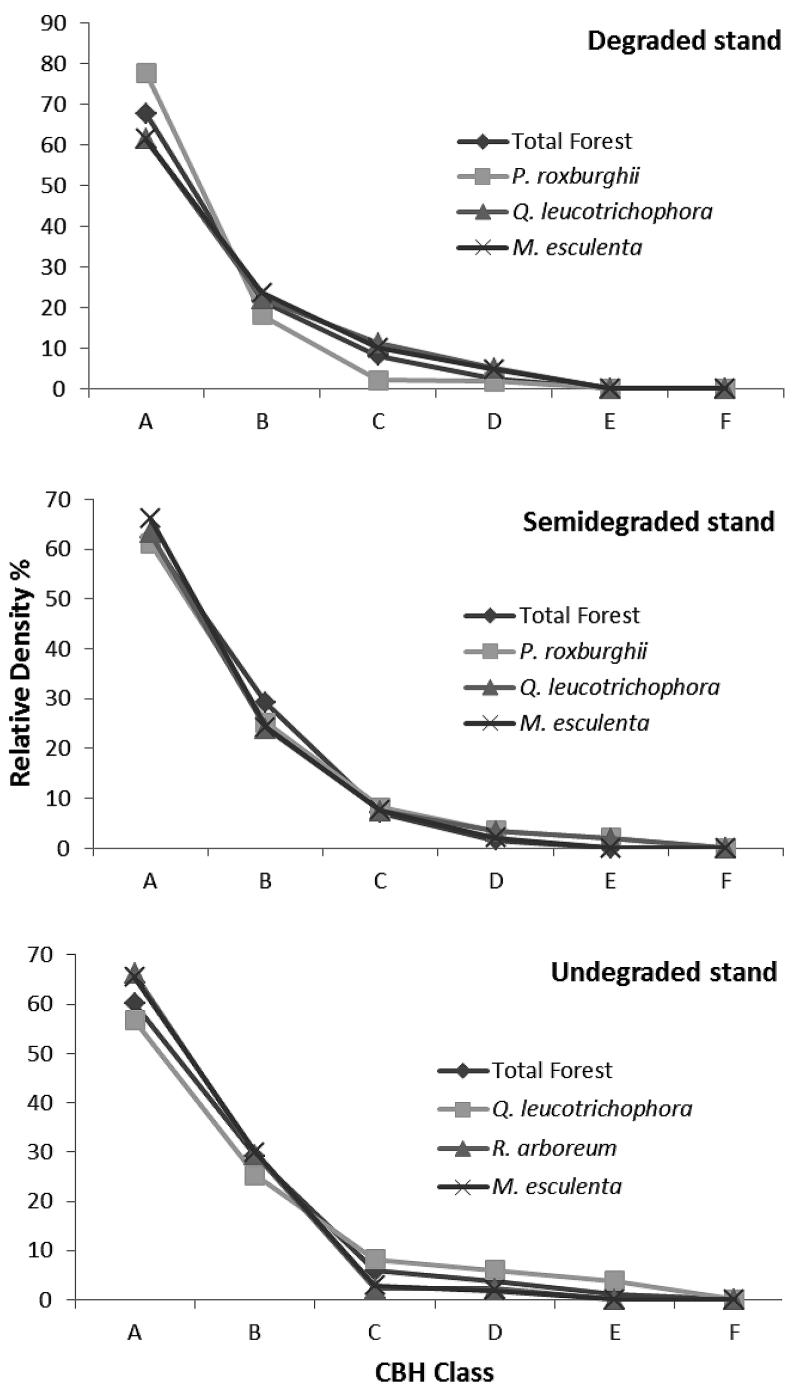

Fig. 3. Patterns of tree size class distribution across disturbance level in Mixed broad-leaf forest

Explanations: A - Seedling, B - Sapling, C - 31-60, D - 61-90, E - 91-120, $\mathrm{F}->121 \mathrm{~cm}$ at $\mathrm{CBH}$ 
and semi degraded conditions was observed. Among other common tree associates, Rhododendron arboreum followed the patterns of the entire forest, whereas, M. esculenta showed relatively sharp decline from seedling to sapling stages in degraded stands.

\section{Discussion}

A significant lowering of tree density and TBA with an increasing level of canopy degradation suggested that the tree stocking (density) and biomass accumulation (assuming TBA represents biomass) in representative west Himalayan temperate broad-leaf forests were sensitive to disturbance intensities. Therefore, canopy disturbance can be suggested as one of the major indicators of compositional changes in the region. Results of this study are in broad agreement with Rawal et al. (2012), which reported sensitivity of compositional attributes towards disturbance levels in mid- to highHimalayan forests, especially the oaks. This sensitivity can be attributed to changes caused in micro-site/habitat conditions by canopy disturbances (Wilkum \& Wali 1974; Baker 1986; Rejmánek 1989). However, with increasing disturbance, significantly declining patterns of density of recruits (i.e., seedlings and saplings), and sharp decline in tree species richness, the mixed broad-leaf forest emerged more sensitive to disturbance intensities as compared to banj-oak forest. This would imply that tree compositional stability of mixed broadleaf forest in the region was severely threatened with increased disturbance; therefore, this forest deserves greater management attention.

Considering trees as dominating life forms of forests, and comparing present study results with an earlier study on forest disturbance in the region (Uniyal et al. 2010), it is evident that the forest tree density became adversely affected by increasing levels of disturbance. This trend remained equally true for both high and low tree density forests. For example, banj-oak forest in previous study by Uniyal et al. (2010) had considerably higher tree density (804-2144 trees ha-1) as compared to the present study (393-789 trees ha-1).

With increasing levels of canopy degradation, the definite decline in the occurrence (relative frequency) and predominance (relative density) of Himalayan native herb species in both forests deserves attention. Significant increase in relative frequency of non-native herbs in degraded stands suggests increasing vulnerability of such sites to likely invasion by non-native species. Earlier, Dhar et al. (1997) attributed greater frequency of non-natives in disturbed sites of central Himalayan forests to gaps created in the forest cover owing to removal of biomass from canopy. Particularly, in these forests, warmer elements of subtropical range find suitable habitats in disturbed sites (Dhar et al. 1997). Furthermore, considering the proportional density of non native herbs, the degraded stands of banj-oak forest can be termed as critically vulnerable to proliferation of non-native herbs.

In spite of a broad similarity in the overall forest population structure across disturbance levels, there was a definite deviation in degraded stands with more prominent decline in numbers of young (class ' $C$ ') tree individuals. This corresponds with an earlier study by Kumar \& Ram (2005) who reported an increasing mean number of young individuals towards undegraded stands. This pattern of tree size class distribution may lead to considerable structural changes of degraded stands in near future. In particular, changes are expected due to relatively faster decline in young tree individuals of common associate species, like $M$. esculenta and $R$. arboreum, as compared to dominant (Q. leucotrichophora) in semi degraded and degraded stands. For mixed broad-leaf forest, frequent presence of $P$. roxburghii as co-dominant in degraded and semidegraded conditions was observed. However analyzing these trends and keeping in view a complete absence of this species in undegraded plots, we predict a likely expansion of this species. As P. roxburghii is reported to occupy forest gaps and proliferate, and since the species has invading nature (Singh \& Singh 1987; Rawal et. al. 1992), the possibility of increase in its dominance on disturbed sites is high.

\section{Conclusions}

This study broadly concludes the following: $(i)$ the forest tree density (stocking) and TBA (Biomass) in temperate broad-leaf forests of west Himalaya is sensitive to increasing levels of canopy disturbance; (ii) the forest tree compositional stability of mixed broad-leaf forests, with greater sensitivity of recruits (sapling and seedlings) and tree species richness, is severely threatened with increasing levels of disturbance, (iii) increased canopy creates better opportunities for the establishment and proliferation of non-native species in the herbaceous layer of the studied forests; and (iv) degraded stands of banj-oak forest are critically vulnerable to proliferation of non-native herbs. These findings can be considered appropriate to define forest management priorities in the region. Particularly, patterns of composition across the disturbance level, as described in the present study, need to be made an integral part of the forest landscape restoration strategy.

Acknowledgments. We thank the Director, GBPNIHESD, Dr. P. P. Dhyani for encouragement and financial support. Thanks are due to Dr. Kailash Gaira for his help and support in statistical analysis. Our thanks are due to an anonymous reviewer for critical comments and suggestions on the earlier version of the manuscript that greatly helped in improving the contents of this paper. 


\section{References}

Adhikari B. S., Rawat Y. S. \& Singh S. P. 1995. Structure and function of high altitude forest of Central Himalaya. I-dry matter dynamics. Ann Bot 75: 237-248.

BAKer H. C. 1986. Patterns of plant invasion in North America. In: H. A. Moony \& J. A. Drake (eds.). Ecology of biological invasion of north America and Hawaii New York, pp. 45-57. Springer Verlag, Berlin.

Dhar U., Rawal R. S. \& Samant S. S. 1997. Structural diversity and representativeness of forest vegetation in a protected area of Kumaun Himalaya, India: implications for conservation. Biodivers Conserv 6: 1045-1062.

Gairola S., Rawal R. S. \& Dhar U. 2009. Patterns of litter fall and return of nutrients across anthropogenic disturbance gradients in three sub alpine forests of west Himalaya, India. J Forest Res 14(2): 73-80.

Gairola S., Rawal R. S. \& Todaria N. P. 2008. Forest vegetation patterns along an altitudinal gradient in sub-alpine zone of west Himalaya, India. Afr. J. Plant Sci. 2(6): 42-48.

Gairola S., Rawal R. S. \& Todaria N. P. 2015. Effect of anthropogenic disturbance on vegetation characteristics of sub-alpine forests in and around valley of flowers national park, a world heritage site of India. Trop Ecol 56(3): 357-365.

Kharkwal G. \& Rawat Y. S. 2010. Structure and composition of vegetation in subtropical forest of Kumaun Himalaya. Afr. J. Plant Sci. 4(4): 116-121.

Kumar A. \& Ram J. 2005. Anthropogenic disturbances and plant biodiversity in forests of Uttaranchal, central Himalaya. Biodivers Conserv 14: 309-331.

Misra R. 1968. Ecology workbook. 244 pp. Oxford and IBH Publication Co. New Delhi.

Mueller-Dombois D. \& Ellenberg H. 1974. Aims and methods of vegetation ecology. 547 pp. John Wiley, New York and London.

Pandey U. \& Singh J. S. 1984. Energy flow relationships between agro and forest ecosystems in Central Himalaya. Environ Conserv 11(1): 45-53.
Ram J., Kumar A. \& Bhatt J. 2004. Plant diversity in six forest types of Uttaranchal, Central Himalaya, India. Curr Sci 86(7): 975-978.

RawaL R. S. 1991. Woody vegetation analysis along an elevational gradient of upper surju catchment. Ph. D. Thesis Kumaun University, Nainital, India.

Rawal R. S., Gairola S. \& Dhar U. 2012. Effects of disturbance intensities on vegetation patterns in oak forest of Kumaun, west Himalaya. J. Mt. Sci. 9(2): 157-165.

REJMÁNEK M. 1989. Invisibility of plant communities. In: J. A. Drake, H. A. Moony, F. di Castri, R. H. Groves, E. J. Kruger, M. RejmÁneK \& M. Williamson (eds.). Biological invasion: a global perspective, pp. 281-300. SCOPE 37: John Wiley \& Sons, New York.

Shannon C. E. \& Wiever W. 1963. The mathematical theory of communication. 117 pp. Urbana Univ. Illinois Press Urbana, III.

Singh J. S. \& SingH S. P. 1987. Forest vegetation of the Himalaya. Bot Rev 53(1): 80-192.

SingH J. S. \& SingH S. P. 1992. Forests of Himalaya: structure, functioning and impact of man. 249 pp. Gyanodaya Prakashan, Nainital, India,

SINGH S. P. 1998. Chronic disturbance, a principal cause of environmental degradation in developing countries. Environ Conserv 25: 1-2.

Singh S. P., Adhikari B. S. \& Zobel D. B. 1994. Biomass productivity, leaf longevity and forest structure in the central Himalaya. Ecol Monogr 64: 401-21.

Snedecor G. W. \& Cochran W. G. 1969. Statistical methods. 593 pp. 6th edition Iowa State University Press. Ames Iowa, USA.

Uniyal P., Pokhriyal P., Dasgupta S., Bhatt B. \& Todaria N. P. 2010. Plant diversity in two forest types along the disturbance gradient in Dewalgarh Watershed, Garhwal Himalaya. Curr Sci 98(7): 938-943.

Wilkum D. A. \& Wali M. K. 1974. Analysis of a North Dakota gallery forest: vegetation in relation to topographic and soil gradients. Ecol Monogr 44: 441-464.

WiLKINSON L. 1986. SYSTAT: The system for statistics. Evanston, IL: SYSTAT, Inc. 